\title{
Adoption of Agricultural Innovations: The Effectiveness of Communication Channels Used in the Diffusion of Zero Grazing among Dairy Farmers in Bureti Sub County, Kericho County, Kenya
}

\author{
Emily Keles Muli \\ School of Science and Technology, University of Kabianga, Kenya
}

\begin{abstract}
This study was carried out to investigate the effectiveness of communication channels on the diffusion and adoption of zero grazing farming method among dairy farmers in Bureti Sub-County of Kericho County. Mixed method research approach was adopted and data was collected using observation, focus group discussions and structured interviews to provide both qualitative and quantitative data. The sample size was determined by a simplified formula provided by Yamane (1967) to obtain a sample of 396 households at $95 \%$ confidence level. The study showed that radio, TV, internet, agro-vets and 'other farmers' were the preferred sources of farming information among dairy farmers in Bureti Sub County. The sources used by change agents - demos/workshops, meetings/barazas and extension workers were rarely used by farmers either as sources of farming information or for decision making in the adoption of zero-grazing method. In decisions to adopt zero-grazing, the radio, the TV and internet were the preferred communication methods.
\end{abstract}

Key words: Food Security, Communication and diffusion of innovations, diffusion of agricultural innovations, zero grazing, zero-grazing in Kenya.

\section{I.INTRODUCTION}

$\mathrm{K}$ enya's dairy sub sector today contributes about $8 \%$ of Gross Domestic Product (GDP) with most farmers being small scale. However, the demand of milk is still much ahead of production which is 3.43 billion litres annually against an increasing demand that had reached about 4 billion liters by 2012. Consumption is estimated to rise by three to four per cent annually driven by increase in population, urbanization and income. It was anticipated that by the year 2020, the consumption would rise to 4.7 billion litres, still far ahead of the anticipated production increase (GoK, 2013; Omunyin, Ruto, Yegon and Bii, 2014). Furthermore, FAO recommends annual per capita milk consumption of 220 litres while the current Kenyan annual per capita milk consumption is 120 litres. More milk is therefore needed to meet the increasing demand (FAO, 2019).

The zero-grazing method of cattle rearing was introduced in Kenya by the National Dairy Development Project (NDDP) in 1979 with the aim of increasing milk production to fill in the gap in the demand. Adoption of the rearing method would ease the problem of small land sizes used for grazing. Specifically, zero grazing has the advantages of reducing the amount of land required for cattle rearing, quick accumulation of manure, ease in control of diseases and parasites, less wastage of feeds, high stocking rate in addition to high milk yield (Odero-Waitituh 2017; Omunyin, Ruto, Yegon, and Bii, 2004;Cheboi and Mberia, 2014).

Bureti Sub-County is one of the areas that were targeted by the Kenya government for the zero grazing programme. With a high milk production potential, the Sub-county can significantly increase milk production, efficiently utilize dwindling land acreage and thus improve the livelihoods of the residents. Currently adoption of zero grazing in the Subcounty stands at a meagre 2,974 out of 28,304 dairy farmers with an average milk production of only three litres per lactating cow (Kericho County Govt, 2014; Ayele and Khanh 2012). According to Tegemeo Institute (2014) dairy farmers can earn up to 12 times more if they adopted zero grazing. The Diffusion of Innovation Theory (DoI) asserts that successful adoption of innovations depends on the effectiveness of communication channels used in the diffusion process (Rogers, 2003; van de Fliert, 2015). The theory seeks to explain how, why, and at what rate new ideas and technology spread. Everett Rogers (2003) defines diffusion as the process by which an innovation spreads overtime within a social system. Four main elements influence the spread of a new idea: the innovation itself, communication channels, time, and a social system. Rogers (2003) identified two broad types of communication channels for diffusion of innovations - mass media and interpersonal communication channels. According to Rogers (2003), while mass media is effective in creating awareness of an innovation, interpersonal communication is important in the decision making process. However, so far, no research has focused on the role of communication channels in the diffusion and adoption of zero grazing in Bureti. This study, therefore, applied DoI theory to examine the channels farmers in Bureti Sub County use for agricultural information and to identify which channels influence farmer decisions on adoption of zero grazing farming method. 


\section{METHODOLOGY}

Mixed method research design was used to examine the channels farmers in Bureti Sub county use for agricultural information and to identify which channels influence farmer decisions on adoption of zero grazing farming method. The farm households totaling 28,304 involved in dairy farming (County Government, 2014) constituted the population of interest. A multistage cluster sampling procedure was used to get a representative sample of households. Purposive sampling techniques were then used to select the respondents consisting of household heads. The sample size was determined by a simplified formula provided by Yamane (1967) to obtain 396 households at $95 \%$ confidence level. A triangulation data collection approach which involved observation, focus group discussions and structured interviews was adopted to provide both qualitative and quantitative data.

\section{FINDINGS}

Socioeconomic characteristics of dairy farmers in Bureti Sub County

The population studied was farming households in Bureti sub County. The research showed that only $16.8 \%$ of the respondents had adopted zero grazing, a marginal increase from 10.5 per cent in 2012 (Ayele and Khanh 2012). Another $6.6 \%$ had adopted and abandoned. Among the respondents, the majority $(54.5 \%)$ were women with men constituting $45.5 \%$. Majority of the respondents $(42.5 \%)$ had primary level of education, while $23 \%$ had secondary level and 22.8 per cent had post-secondary education. Only 11 per cent reported having no education at all. Reflecting an increasing number of youth taking up farming, the study showed that $39 \%$ of the respondents were less than 35 years with the age group of between 35 and 50 years accounting for $24 \%$ while $37 \%$ were aged 50 and above. Farm sizes reflected a growing trend of dwindling acreages per household with a staggering $60.5 \%$ of the respondents owning less than an acre. Another $20.4 \%$ had between one and two acres while a further $9 \%$ had up to three acres. Only 3\% had more than 4 acres (Table 1) - a rapid decline from the 3 acre average reported in 2019 (Ng'eno, 2019).

Table 1: Farm Size in Acres

\begin{tabular}{|c|c|c|}
\hline & Frequency & Percent \\
\hline Less than 1 acre & 101 & 60.5 \\
\hline $1-1.9$ acres & 34 & 20.4 \\
\hline $2-2.9$ acres & 15 & 9.0 \\
\hline $3-3.9$ acres & 12 & 7.2 \\
\hline 4 acres and above & 5 & 3.0 \\
\hline Total & 167 & 100 \\
\hline
\end{tabular}

A similar trend is reflected by the number of dairy cows kept by the house holds where $41.9 \%$ had 2 cows or less and another 43.1 per cent had between 3 and five cows. Only 11 percent had more than 6 dairy cows (Table 2). Ng'eno. (2019) indicated that on average households in Bureti kept two cows.

Table 2: Number of Dairy Cows Per Household

\begin{tabular}{|c|c|c|}
\hline & Frequency & Percent \\
\hline None & 6 & 3.6 \\
\hline $1-2$ cows & 70 & 41.9 \\
\hline $3-5$ cows & 72 & 43.1 \\
\hline 6 cows and above & 19 & 11.4 \\
\hline Total & 167 & 100.0 \\
\hline
\end{tabular}

Usage of media for dairy farming information by farmers in Bureti Sub County

In mass media usage by dairy farmers, a surprising trend is reflected in the increasing use of internet at $18.6 \%$, almost rivaling $\mathrm{TV}$ at $25.1 \%$. Traditional mass media such as newspapers showed a lower usage rate at $4.8 \%$. In deed those who access print media daily are a paltry $3.6 \%$ while internet daily access rate was $6.6 \%$ (Table 3 ). This is starling trend given the fact that media such as internet are new, more expensive and require a certain amount of education to benefit the individual. Its greatest benefit, according to a majority of the respondents, is its ability to elicit immediate feedback thus offering an interactive opportunity to learning.

Table 3: Usage of Media for Farming Information by Dairy Farmers

\begin{tabular}{|c|c|c|}
\hline & Frequency & Percent \\
\hline Radio & 86 & 51.5 \\
\hline TV & 42 & 25.15 \\
\hline Internet & 31 & 18.56 \\
\hline print media & 8 & 4.79 \\
\hline Total & 167 & 100.00 \\
\hline
\end{tabular}

Usage of interpersonal communication for dairy farming information by farmers

This study sought to establish the importance of interpersonal channels as information sources by asking respondents to rank the preferred interpersonal channels for accessing farming information. The results are shown on Table 4. Demos and field days, agricultural shows, meetings and barazas as well as extension workers - all favored by change agents for introducing their innovations - were still favorably mentioned, but the preferred interpersonal sources of farming information for famers in Bureti Sub County were agro vets $(26.3 \%)$ and other farmers $(16.8 \%)$ followed by demos. The rise of agro vets - a group rarely mentioned among farmer decision making influencers - could be due to their availability in the villages making them accessible to the farmers 
Table 4: Use of Interpersonal Communication Channels for Farming Information

\begin{tabular}{|c|c|c|}
\hline & Frequency & Percent \\
\hline demos and field days & 25 & 15.0 \\
\hline Agricultural shows & 15 & 9.0 \\
\hline meetings/Barazas & 21 & 12.6 \\
\hline extension officers & 10 & 6.0 \\
\hline Agro vets & 44 & 26.3 \\
\hline others farmers & 28 & 16.8 \\
\hline family members & 14 & 8.4 \\
\hline NGOs & 7 & 4.2 \\
\hline Churches & 3 & 1.8 \\
\hline Total & 167 & 100.0 \\
\hline
\end{tabular}

According to Rogers (2003) interpersonal contacts provide information that influence opinion and judgment. Indeed, in their study, Efficacy of Interpersonal Communication Channels in the Diffusion and Adoption of Zero Grazing Technology, Cheboi and Mberia (2014) list interpersonal communication channels as the main sources of information on zero grazing among farmers.

Communication channels which influenced farmer decision to adopt Zero Grazing technology

More intriguing were the answers to the question: What communication channels influenced your decision to adopt zero-grazing? The results showed that the internet mentioned by $7.2 \%$ of the respondents is gaining greater importance in decision making contrary to expectations (Cheboi and Mberia, 2014; Rogers, 2003). This seems to confirm the observation of the expanded role of internet to influence the decision making process of farmers to adopt innovations (Mishra and Williams, 2006). Stuart, Russo, Sypher, Simons and Hallberg (2001) also found that an increasing number of farmers go online daily but the researchers continue to hold the view that the farmers use internet as source of information only in the early stage in their adoption of the technology. It is however, important to note that the value of the internet extends beyond its role in informing and awareness raising activity to playing an increasingly significant role in decision making. Radio cited by $26.3 \%$ of the respondents and TV cited by $13.8 \%$.of the respondents were also among the most cited for influencing farmer decisions to adopt zero grazing technology. Other important influencers were 'other farmers' (30.5\%). Demos/workshops, meetings/barazas and extension workers, which are preferred by the change agents, ranked low at $1.2 \%, 4.8 \%$ and $1.8 \%$ respectively. The print media (newspapers and magazines) held a bottom rank with only $1.8 \%$. The low showing of the print media may be attributed to their lack of interactive capacity and immediacy.
Table 5: Which Channels of Communication Influenced Farmer Decision to Adopt Zero Grazing Technology?

\begin{tabular}{|l|r|r|}
\hline & Frequency & \multicolumn{1}{|c|}{ Percent } \\
\hline Radio & 44 & 26.3 \\
\hline TV & 23 & 13.8 \\
\hline newspaper and magazines & 3 & 1.8 \\
\hline Internet & 12 & 7.2 \\
\hline demos/workshops & 2 & 1.2 \\
\hline meetings/barazas & 8 & 4.8 \\
\hline extension workers & 3 & 1.8 \\
\hline Agro vets & 15 & 9.0 \\
\hline other farmer & 51 & 30.5 \\
\hline family members/friends & 4 & 2.4 \\
\hline NGOs & 2 & 1.2 \\
\hline Total & 167 & 100.0 \\
\hline
\end{tabular}

\section{SUMMARY AND CONCLUSIONS}

This study showed that radio, TV, internet, agro vet and 'other farmers' were the preferred sources of farming information among dairy farmers in Bureti Sub County, Kericho, Kenya. The sources normally used by innovators - demos/workshops meetings/barazas and extension workers (Rogers, 2003, Cheboi and Mberia, 2014) were rarely used by farmers as the preferred sources of farm information. Most of the respondents cited the mass media (the radio, the TV and internet) as well as 'other farmer', as the communication channels that influenced their decisions to adopt zero grazing technology, indicating an increasing role of the mass media in influencing decisions to adopt innovations. The increase in farming programs, low prices, accessibility and portability of the radio and smart phones were mentioned as the reasons for their influence. However, the TV is a special case. While increasing availability of electricity has made it accessible, it is still an expensive item. Like the internet, an increase in farming programs, their ability to demonstrate what is being discussed, coupled with their interactive nature was mentioned as reasons for their influence. Indeed, one farmer said that he watched any farming program on TV regardless of whether he understood the language in which it was presented or not. As Stuart, Russo, Sypher, Simons, Hallberg, (2001) point out, the number of farmers going online daily is increasing, permitting the formation of online communities (or virtual communities) and access to cultural and social networks beyond an individual's locality (Mishra and Williams,2006). That redefines our conception of interpersonal communication. The future for diffusion and adoption of farming innovations such as zero grazing may lie on the internet, radio and TV which have possibilities for interactive communication coupled with the ability to demonstrate. The portability of the internet with its ability to provide real time responses and create online communities 
will possibly continue to strengthen its importance in the diffusion and adoption of farming innovations.

\section{ACKNOWLEDGEMENT}

Research reported in this publication was supported by a grant from University of Kabianga, Kericho, Kenya. The content is solely the responsibility of the author and does not necessarily represent the official views of the University of Kabianga.

\section{REFERENCES}

[1] Ayele, Duncan, Larbi, and Khanh 2012. Enhancing innovation in livestock value chains through networks: Lessons from fodder innovation case studies in developing countries. Oxford University Press

[2] Balit, S. (2006). Communication - key to effective development. The Journal of Development Communication,

[3] Cheboi S., and Mberia H., 2014. Efficacy of Interpersonal Communication Channels in the Diffusion and Adoption of Zero Grazing Technology. IJARBSS

[4] Government of Kenya, 2013. Sessional Paper No. 5 of 2013 on the National Dairy Development Policy

[5] FAO, 2019. Dairy market review - Price and policy update, FAO Publications
[6] Kirui J. C, Owuor B. and Muhingi W.N, (2018) Farmers' Dairy Practices as a Constraint Facing Small-Scale Dairy Farmers in Cheborge in Kericho County, Kenya, IJH\&SS

[7] Odero-Waitituh J A, (2017) Smallholder dairy production in Kenya; a review. Livestock Research for Rural Development.Volume 29, Retrieved June 19, 2021, from http://www.lrrd.org/lrrd29/7/atiw29139.html

[8] Omunyin, M. E., Ruto, J. Yegon, M. K. A and Bii, F, 2014. Dairy Production Constraints in Kericho and Bomet Counties of Kenya: Evidence from Farmers Fields. IJSR

[9] Rogers E., 2003. Diffusion of Innovations

[10] Thomas P., van de Fliert, E., 2015. Interrogating the Theory and Practice of Communication for Social Change: The Basis for a Renewal (Palgrave Studies in Communication for Social Change)

[11] Ng'eno E. K. (2019), Determinants of farm-gate marketed milk output volumes in Kericho County, Kenya, International Journal of Development and Sustainability

[12] Wellard K., and Mortimore M., 2000, Farmer-led adoption of ox weeding in Machakos District, Kenya in Animal power for weed control: A resource book of the Animal Traction Network for Eastern and Southern Africa (ATNESA), Technical Centre for Agricultural and Rural Cooperation (CTA), Wageningen,

[13] William D. S., Tracy C. R,, Howard E. S., Thelma E.S, and Lisa K. H., 2001. Influences of Sources of Communication on Adoption of a Communication Technology in Diusing Software Product and Process Innovations, IFIP 